\title{
大腸菌におけるペプシノゲン蛋白産生
}

\author{
一瀬雅夫*・東一正*・遠藤康夫*・市原慶和**・岡博* \\ 降旗千恵***・丹治雅夫**・景山 節**** 高橋健治**
}

\begin{abstract}
SUMMARY
Several plasmids have been constructed which direct the synthesis of rat pepsinogen or prepepsinogen in Escherichia coli. When plasmids with the $E$. coli lac promoter was introduced into $E$. coli, a protein identified as pepsinogen or prepepsinogen by immunoreactivity and SDS-PAGE was synthesized in the form of fused protein with $\beta$-galactosidase. They constituted up to $2.5 \%$ of the total cellular protein and formed insoluble aggregate in E. coli. They were solublized by urea extraction, but no pepsin activity was detected in these proteins. In these proteins, both intra and intermolecular activation from pepsinogen to pepsin was impaired. This impairment of the activation step was probably due to the structural change of the $\mathrm{N}$-terminal regions of these proteins rather than the degeneration by urea extraction.
\end{abstract}

Key words : pepsin-pepsinogen, gene recombination, Escherichia coli

\begin{abstract}
緒言
カルボキシルプロテアーゼ（アスパラギン酸プロテ アーゼ）の代表的酵素であるペプシンは，塩酸，ム千 ンと共に胃液の三大構成成分の一つを成し，その不活 性前駆体であるぺプシノゲンは胃内腔に分泌されると 酸性 $\mathrm{pH}$ 下で自己触媒的に活性型ペプシンに変換され る. ペプシン・ペプシノゲンは, 酵素学的な興味以外 にも, 消化生理学的意義や, 潰瘍発生に関連して攻撃 因子としての病態生理学的意義等, 消化器病学の上で
\end{abstract}

興味ある問題を多く含む酵素系である．近年の遺伝子 組み換え技術の進歩は, 従来の手法では不可能であっ た, 多くの遺伝子の構造解析を可能とし，ヒト・ペプ シノゲンの一次構造も DNA レベルで決定された ${ }^{11}$. 一方，クローニングした動物遺伝子を大腸菌における 遺伝情報の発現シグナル（プロモーター, リボソーム 付着信号等) に接続し, 大腸菌に導大, 発現させて遺 伝子産物を蓄積させる試みが活発に行なわれるように なっており,これまでに, ホルモン, 酵素, インター フェロン, 癌遺伝子蛋白等, 種々の動物遺伝子蛋白お

Expression of cloned pepsinogen gene in Escherichia coli.

Masao Ichinose*, Kazumasa Miki*, Yasuo Endo*, Yoshikazu Ichihara**, Hiroshi Oka*, Chie Furihata**,

Masao Tanji***, Takashi Kageyama**** and Kenji Takahashi***

*東京大学第一内科； First Department of Internal Medicine, Faculty of Medicine, University of Tokyo,

**同, 理学部生物化学; Department of Biophysics and Biochemistry, Faculty of Science, University of Tokyo,

***同, 医科研癌生物 ; Department of Molecular Oncology, Institute of Medical Science, University of Tokyo.

****京都大学霊長類研究所生物化学; Department of Biochemistry, Primate Research Institute, Kyoto University.

Correspondence address: Masao Ichinose, First Department of Internal Medicine, Faculty of Medicine,

University of Tokyo, Bunkyo-ku, Tokyo 113, Japan.

（受付 1987 年 7 月 22 日，受理 1987 年 9 月20日） 


\section{（414） 生物物理化学}

よびウイルス蛋白の大腸菌での産生が試みられてい $る^{2 \sim 9)}$. この種の試みは, 外来遺伝子の発現を指標とし て遺伝子制御の上で問題となる一般事項および遺伝子 産物の細胞内蓄積, 細胞外移送等の条件の検討や, 特 定部位指向突然変異導入法 (Site-directed mutagenesis) を用いて人工変異蛋白を調整し，遺伝子 産物の構造と機能相関性の比較解析等, 単に蛋白産物 の大量生産の目的以外にも，有効な実験系となってい る．われわれもクローニングしたラットのペプシノゲ ン遺伝子 ${ }^{10)}$ を発現ベクターに接続し, 大腸菌に導入, ペ プシノゲンあるいは，プレペプシノゲン蛋白を大腸菌 に発現させる試みを行なったので報告する。

\section{方 法}

\section{1 ）発現ベクターの作製}

大腸菌内で組み換えぺプシノゲン遺伝子を発現させ るベクターとして，プロモーター活性の調節が可能 (switch-on が可能) な $\lambda$ ーファージの PL プロモータ 一および大腸菌のラクトース・オペロンのプロモータ 一 (lac プロモーター)を持つプラスミドである, pPL ー入および PUC-12 を選んだ(Fig. 1). 前者は，レプレ ッサーの温度感受性変異株 (cI 857 など) に導大し, 培 養温度を上昇させる事で，また，後者は培養液中にラ クトース・オペロンの非代謝性誘導物質 (isopropyl$\beta, D$-thiogalactoside ; IPTG 等)を添加する事で，そ れぞれのレプレッサーを不活性化出来，プロモーター の下流に組み込んだ異種遺伝子の発現を誘導させる事 が出来るプラスミドである.pPL-入では, PL プロモー ターと共に $\lambda$-ファージの N 遺伝子を含む断片が組み 込まれており，N 遺伝子中の制限酵素 Hpa I 認識部 位に遺伝子断片を挿入する事で, PL プロモーターの調 節下 $\mathrm{N}$ 遺伝子蛋白とのハイブリッド蛋白の形で産生 させる事が出来る。またPUC-12 では組み込まれた $\beta$ 一ガラクトシダーゼ遺伝子中に, 制限酵素認識部位の連 なった DNA 鎖が組み込まれており，ここに遺伝子断 片を挿大する事で， $\beta$-ガラクトシダーゼとのハイブリ ッド蛋白が，lac プロモーターの調節下に産生される。 これらの発現ベクターに挿大する DNA fragment と して,ラットペプシノゲン c-DNA (pRPC-1) ${ }^{10)}$ より制 限酵素 Pvu II および Xba I を用いて切り出した約 1 . $2 \mathrm{~kb}$ の fragment PX ; $5^{\prime}$ 末端15塩基およびプレペプシ ノゲンをコードする領域を含む fragment) と，制限酵 素 Ava IIの部分消化および XbaIにより切り出した
A)
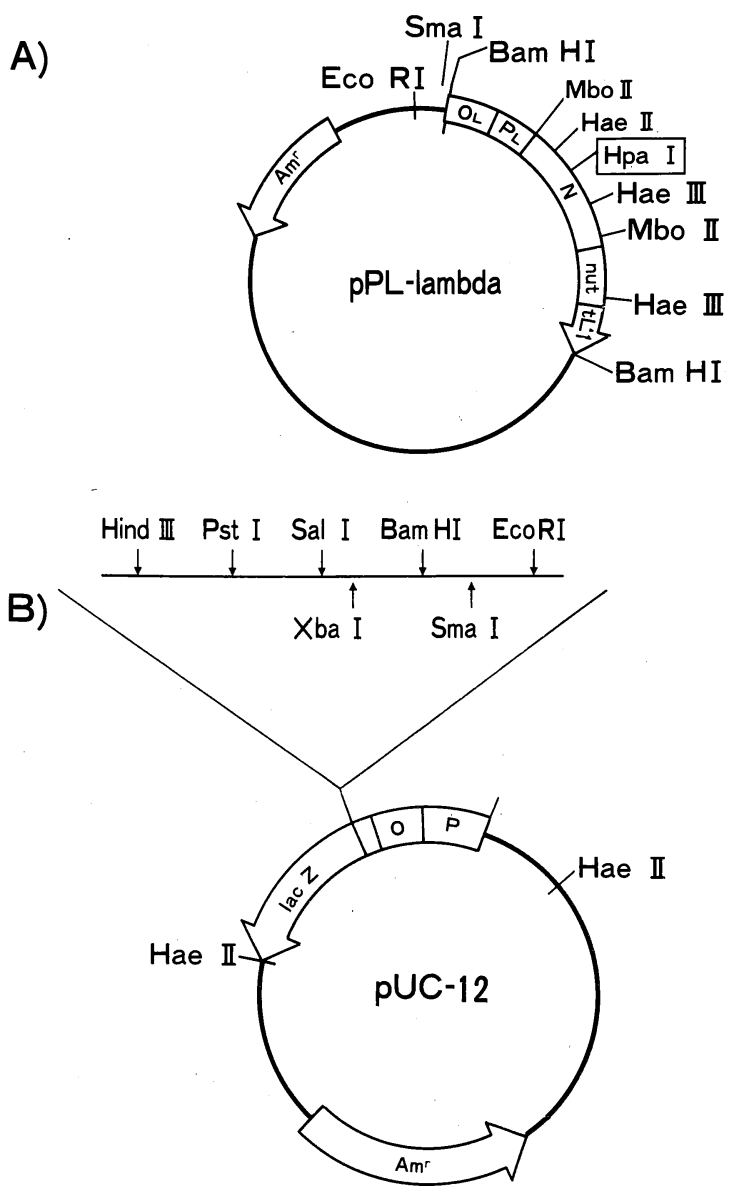

Fig. 1. Expression vectors.

約 $1.1 \mathrm{~kb} の$ fragment (AX ; ペプシノゲンをコードす る領域から $5^{\prime}$ 側12塩基を除いた領域を含む fragment）を用いた（Fig. 2)。これらのPX， AXの両 fragment で処理した後, 制限酵素 Hpa I で切断し，アルカリフ オスファターゼ処理をした $\mathrm{pPL}-\lambda に \mathrm{~T}_{4}$ リガーゼで つないだ(pPL-AX，pPL-PX)。また PUC-12 は，制 限酵素 Sma I と Xba I で切断後, アルカリフォスファ ターゼ処理し, PX および $\mathrm{AX}$ の両 fragment と $\mathrm{T}_{4}$ リ ガーゼにてつないだ (PUC-AX, PUC-PX)。このよ うにして作製された組み換えプラスミドにより発現さ れる蛋白は， $\mathrm{N}$ 遺伝子蛋白あるいは $\beta$-ガラクトシダ 一ゼとペプシノゲンないしはプレペプシノゲンとが, 前述のようにハイブリッド蛋白の形をとって産生され 


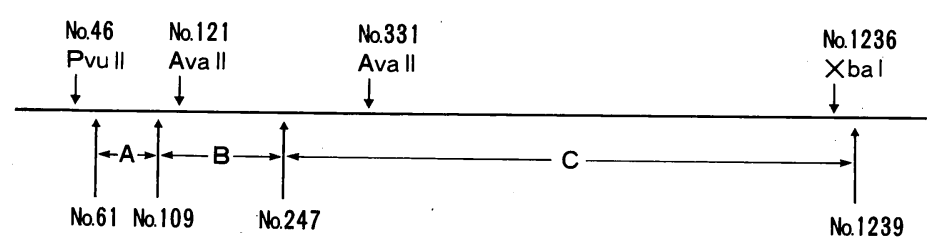
A-Signal peptide
B-Activation peptide C-Pepsin
$A+B+C$ Prepepsinogen
$B+C$ Pepsinogen

Fig. 2. Restriction digestion map of rat prepesionogen c-DNA.

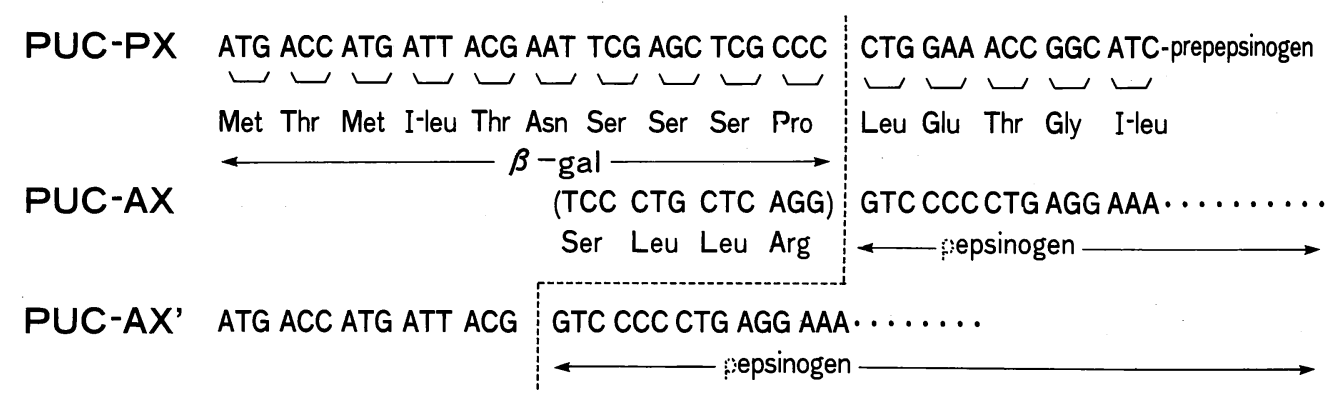

Fig. 3. Predicted structures of proteins expressed by recombinant plasmids with lac promoter.

ると考えられた. Fig. 3 に, PUC-PX および PUC-AX より産生される蛋白の構造を示す。また, PUC-PXを 制限䤃素 EcoRI と AvaII で切断し, Mung-bean nuclease および $T_{4}$ リガーゼ処理にて,$\beta$-ガラクトシダ 一ゼ部分を短くした PUC-AX'を得たが，このプラス ミドにより産生される蛋白の構造も同時に示す。これ らの組み換えプラスミドを，塩化カルシウム処理 ${ }^{11)}$ 用いて, pPL-AX, pPL-PX は，大腸菌 N 4890株へ， また PUC-AX, PUC-PX は, 大腸菌 JM 103株へ導入 して，アンピシリン耐性による選択を加える事で，プ ラスミド保持菌を種々の条件下で培養し, その産生蛋 白を検討に用いた。

細菌蛋白の分画は, Neu らの方法息あるいは Burgessらの方法 ${ }^{13)}$ をいて行なった。蛋白の分析は Laemmli の方法による SDS 電気泳動 ${ }^{14}$ および免疫ブ ロッティングを用いた。ラットペプシノゲンの精製, 抗体の作製, そしてぺプシノゲン活性の測定は既 報15 17)の如く行なった。また，ラット肝臓のマイクロ ゾーム分画は，通常の方法 ${ }^{18}$ に準じてこれを得た。

\section{結 果}

Fig. 4 に, lac プロモーターを使用した, プラスミド 保持菌蛋白の SDS 電気泳動を示す.ペプシノゲン蛋白 の分子量に一致する部分に大腸菌蛋白のバンドがある 為, ゲルパ夕ーンからは蛋白の産生は, はっきりしな い.しかし同じゲルの免疫ブロッティングの結果は, PUC-AX およU゙PUC-PX でペプシノゲンと免疫学 的に交叉性のある分子量 4 万前後の蛋白の産生がある 事を示し, これらの蛋白の産生は, IPTG の培地一の添 加により 2 倍前後增加する事から, lac プロモーター に支配されていると考之られ，発現ベクターに組み込 まれたラットペプシノゲン遺伝子の産生蛋白と考之ら れた.一方, pPL-AX および pPL-PX では抗ペプシ） ゲン抗体と反応する蛋白の産生は認められなかった。 精製したラットペプシノゲンをコントロールにした結 果から，PUC-AX および PUC-PX で産生されるこれ らの蛋白は, 全菌体蛋白の $2.5 \sim 0.5 \%$ 前後を占めてい ると考えられた，PUC-PXの蛋白スポットは, マーカ 


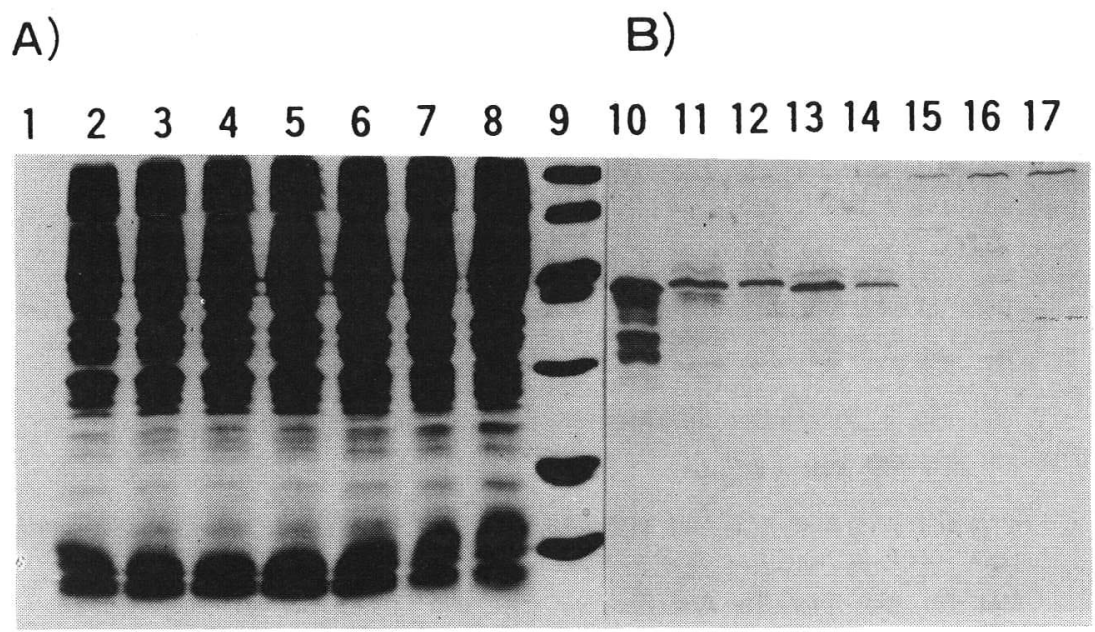

Fig. 4. Proteins synthesized by $E$. coli containing plasmids PUC-AX or PUC-PX.

A) SDS-PAGE. B) Immuno-blotting with anti-rat pepsinogen antibody. Lanes 1 and 10, rat pepsinogen: Lanes 2, 3, 11 and 12, E. coli JM 103 containing plasmid PUC-PX ( 2 and 11 grown in the presence of IPTG) : Lanes 4, 5, 13 and 14, JM 103 containing plasmid PUC-AX (4 and 13 with IPTG) : Lanes 6, 7, 15 and 16, JM 103 containing plasmid PUC-12 (6 and 15 with IPTG) : Lanes 8 and 17, JM 103 : Lane 9, marker proteins (lysozyme $14.4 \mathrm{~K}$, soy bean trypsin inhibitor $21.5 \mathrm{~K}$, carbonic anhydrase $31 \mathrm{~K}$, oval. bumin $45 \mathrm{~K}$, BSA $66.2 \mathrm{~K}$, phospholylase B $92.5 \mathrm{~K}$ ).

一ペプシノゲンおよび PUC-AXの蛋白スポットに比 し，分子量が多少大きく，プレペプシノゲンをコード する fragment を挿入されている事に一致すると考え られた．Fig. 5 に示すごとくこれらの蛋白は可溶分画 に存在せず細胞内にて不溶性の aggregate を形成し て存在しており，6 9M 尿素抽出で可溶化回収され た。これらの分画についてペプシン活性を Anson

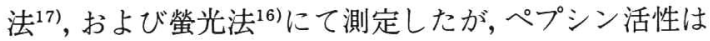
認められなかった、ペプシン活性の認められない理由 を検討する為に，これらのサンプルを $\mathrm{pH} 2.0$ とし， $14^{\circ} \mathrm{C}$ にて 8 時間インキュベーションした後, 免疫ブロ ッティングにより検討した所，これらのサンプルでは 活性型ペプシンの出現が認められず，ペプシノゲンか らペプシンへの変換ステップが障害され， intramolecularly に活性化が起こらないと考えられた (Fig. 5). 精製ラットペプシノゲンを PUC-AX および PUC-PX の尿素抽出分画に添加し，これらの蛋白が intermolecularly に活性化されるかを同様に検討した が, 添加したラットペプシノゲン以外の活性の誘導は
認められなかった．また，PUC-PXの産生するプレぺ プシノゲンと $\beta$-ガラクトシダーゼのハイブリッド蛋 白が，プレプロテインをプロセシングするシグナルペ プチダーゼの基質となり得るかを検討する為，ラット の肝臓より精製したマイクロゾーム分画と PUC-PX の尿素抽出分画を共にインキュベーションし，ブロッ ティングにて検討を行なったが，ペプシノゲン分子お よびペプシン活性の出現は共に認められなかった。

\section{考察}

ラットペプシノゲン遺伝子を大腸菌に導入して，発 現させる事を試みたが，一般に，大腸菌等の宿主細胞 に導入したクローン化した遺伝子の発現が効果的に行 なわれる為には，転写と翻訳の両反応をはじめとした 種々の調節因子がうまく機能するとともに，蛋白産物 が細胞内で化学的に安定である事が必要である。しか し，これらの点に関する知識の集積は不充分であり， 目的とする蛋白を大腸菌などに充分産生させ得た例は あまり多くない. 発現べクターとして, 被誘導性の lac 
A) B)

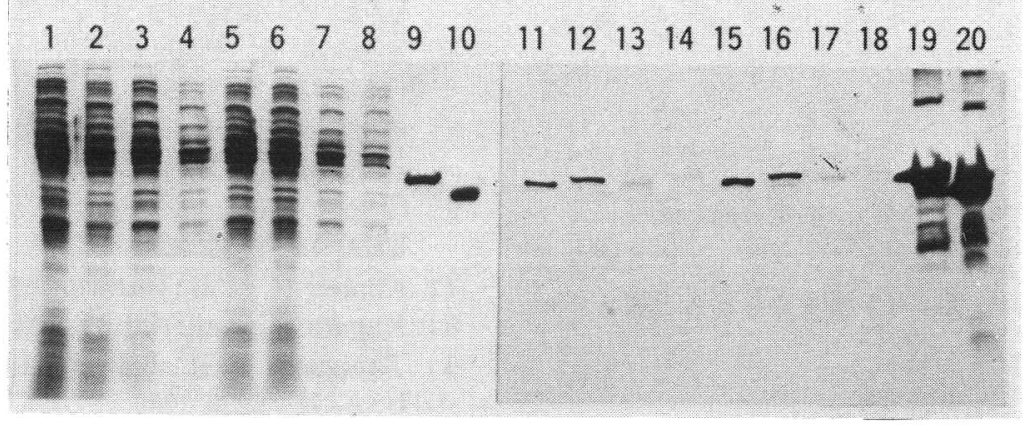

Fig. 5. E. coli JM103 containing plasmids PUC-AX and PUC-PX were disrupted by lysozyme/sodium deoxycholate and separated into supernatant and cell pellet.

A) SDS-PAGE B) Immunoblotting of the same gel with anti-rat pepsinogen antibody.

Lanes $1,3,5,7,11,13,15$ and 17, JM103 containing PUC-AX (1, 5, 11 and 15, pellet : $3,7,13$ and 17 , supernatant).

Lanes $2,4,6,8,12,14,16$ and 18, JM103 containing PUC-PX (2, 6, 12 and 16, pellet : $4,8,14$ and 18 , superantant).

Lanes $9,10,19$ and 20, rat pepsinogen. Samples applied in lanes 5-8, 10, 15-18 and 20 were incubated for 8 hs at $\mathrm{pH} 2.0$ and $14^{\circ} \mathrm{C}$.

プロモーター，及びPL プロモーターを持つものを選 んだが，これは，ペプシノゲン遺伝子の蛋白産物が大 腸菌に有害である場合には，導入した遺伝子の発現を 抑制した条件で細胞数がある程度増加するまで培養を 行ない，その後，遺伝子発現を誘導する事が好都合と 考えられるからである。動物遺伝子を大腸菌で発現さ せる実験において，基本的には二通りの方法が考えら れる。即ち，本来の蛋白質を直接産生させる方法と大 腸菌蛋白との八イブリッド蛋白を産生させる方法であ る.われわれはぺプシノゲン蛋白を大腸菌の $\beta$-ガラク トシダーゼあるいは $\lambda$ ーファージの $\mathrm{N}$ 遺伝子蛋白との 八イブリッド蛋白として生産させる方法を選んだが, この方法が前者に比して比較的容易であるばかりか, m-RNA から蛋白への翻訳開始に大きな影響を与之 るリボソーム付着信号部位や，翻訳開始コドン部位の 構造変化を最小限にとどめ産生された動物蛋白の大腸 菌の内部での安定性を高菌体内での遺伝子産物の 蓄積の目的から見てすぐれていると考之られるからで ある。われわれの作製した発現ベクターから転写され る蛋白では，ペプシン活性が認められなかった。この 事については，尿素抽出の過程で生ずる変性の可能性 が，当然考えられる事であるが，ペプシノゲンを尿素 で処理をしてもかなりの活性が認められるが，本実験

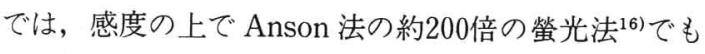
全く活性が認められていない事から，むしろ産生され た蛋白が $\beta$-ガラクトシダーゼとのハイブリッド蛋白 である事に原因があると考えられる。すなわち，大腸 菌で産生されたプレペプシノゲンは $\beta$-ガラクトシダ 一ゼの10アミ/酸を含む15個のアミ/酸が余分につい ており，またぺプシノゲンは， $\mathrm{N}$ 末端の 4 個のアミ， 酸を除いたものに， $\beta$-ガラクトシダーゼの $\mathrm{N}$ 末端ア ミノ酸10個をつけたものである。この変化がペプシノ ゲン蛋白の活性化部位周辺の立体構造を変化させ, $\mathrm{pH}$ の変化により生ずる intramolecularly な活性化ある いは活性型ペプシンの存在下で生ずる intermoleculary な活性化の過程で, 活性化ぺプチドの遊離 老阻害している事は充分考之られる，われわれは， $\beta^{-}$ ガラクトシダーゼの影響を考慮して PUC-AX の N 末端の $\beta$-ガラクトシダーゼのアミノ酸を 5 個に減ら したもの（PUC-AX'）も作製して検討したが，同様 に, このプラスミド保持菌蛋白の尿素抽出分画では, ペプシン分子および活性の出現を認めなかった。ブタ のペプシノゲン c-DNA を同様に大腸菌に導入した実 験において， $\beta$-ガラクトシダーゼの $\mathrm{N}$ 末端の 5 アミ ノ酸とペプシノゲンの $\mathrm{N}$ 末端 4 アミノ酸を除いた蛋 白とのハイブリッド蛋白では活性が認められている 
事 ${ }^{19)}$ 考慮すると, ペプシノゲンの $\mathrm{N}$ 末端の構造はぺ プシノゲンの活性化部位にかなり微妙な影響を与えて いると考えられる。このペプシノゲンの構造と機能の 問題は，このような大腸菌などで産生される人工蛋白 の系が1つの解決を与えると考えられ，このようにし て得られる情報はペプシノゲンの消化性潰瘍の病態生 理に果たす役割の理解を深め, 治療理論の発展に寄与 するとともに, ペプシノゲンアイソザイムの意義など の未解決な問題の解明にも手掛りを与えると考えてい る.

\section{まとめ}

クローニングしたラットペプシノゲン c-DNA を発 現ベクターに組み込み大腸菌に導入, ペプシノゲン蛋 白の発現を試みた。大腸菌のラクトースプロモーター を使用した系において， $\beta$-ガラクトシダーゼとぺプシ ノゲンあるいはプレペプシノゲンとのハイブリッド蛋 白の産生を見た。これらの蛋白は，全大腸菌蛋白の 2.5 0.5\%を占め, 不溶性の aggregate として存在 し，尿素抽出にて可溶性蛋白として回収された。しか し,これらの蛋白は酸性 $\mathrm{pH}$ 下, あるいはペプシンの存

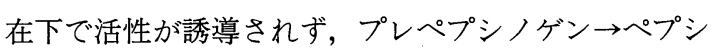

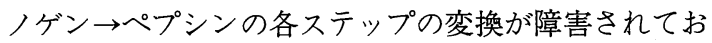
$\eta$, これらの蛋白では, $\mathrm{N}$ 末端の構造変化が活性の誘 導を妨げていると考えられた。

\section{文献}

1) Sogawa K, et al : J. Biol. Chem., $258: 5306$, 1983.
2) Seeburg PH, et al : Nature, $276: 795,1978$.

3 ) Goeddel DV, et al: Proc. Natl. Acad. Sci. USA, $76: 106,1979$.

4) Ratzkin B, et al: Proc. Natl. Acad. Sci. USA, $78: 3313,1981$.

5 ) Emtage JS, et al: Proc. Natl. Acad. Sci. USA, $80: 3671,1983$.

6 ) Gilmer TM, et al: Proc. Natl. Acad. Sci. USA, $79: 2152,1982$.

7 ) Küpper H, et al : Nature, $289: 555,1981$.

8) Nagata $S$, et al: Nature, $284: 316,1980$.

9 ) Taniguchi $T$, et al:Proc. Natl. Acad. Sci. USA, $77: 5230,1980$.

10) Ichihara $Y$, et al : Eur. J. Biochem., 161: 7, 1987.

11) Mandel M, et al : J, Mol. Biol., 53 : 154, 1970.

12) Neu HC, et al: J. Biol. Chem., $240: 3685$, 1985.

13) Burgress RR, et al: J. Biol. Chem., 244 :. 6160, 1969.

14) Laemmli UK : Nature, $227: 680,1970$.

15) Furihata C, et al : Eur. J. Biochem., $105: 43$, 1980.

16) Furihata $C$, et al : Anal. Biochem., $84: 479$, 1978.

17) Anson ML, et al : J. Gen. Physiol., $22: 79$, 1939.

18) Hogeboom GH: Methods in Enzymology, vol 1, p14, edited by Colowick S. P. and Kaplan N. D. Academic Press, New York, 1955.

19）塚越規弘, 他：日本農芸化学会講演要旨集 $60: 443,1985$. 